https://doi.org/10.18485/iipe_euchanges.2021.ch13

\title{
POLITICAL RELATIONS BETWEEN GERMANY AND THE UNITED STATES DURING THE TRUMP PRESIDENCY
}

\begin{abstract}
Miloš PETROVIĆ ${ }^{1}$
Abstract: The focus of this research was the growingly challenging political relationship between Germany and the US during the presidency of Mr. Donald Trump. The first research aim is to examine the evolution of the USGerman partnership from the mid-20 ${ }^{\text {th }}$ century onwards and to depict the instrumental role of the United States in shaping Germany's foreign policy. The second research aim is to consider which aspects of their cooperation were the most affected during the presidential term of Donald Trump. The author identifies several levels of political dissension between two sides during the Trump presidency: firstly, diverging perspectives on integrative processes and international organizations, secondly, discrepancies in the political narratives domain, and thirdly, disparities in the bilateral domain, including the geopolitical and trade distinctions. Through the historical approach, the author clarifies that German international political interests have been strategically embedded in the integration processes within the European Union and other international organizations. Realist theoretical basis is used to scrutinize the evolution of contemporary US-German political cooperation, including the sovereigntist and unilateral tendencies during the Trump administration. The author concludes that not only the US-German but also the US-EU strategic cooperation was significantly impaired during the Trump presidency. Although it might be too early to make predictions, President-Elect Joseph Biden has announced the need for restoring the
\end{abstract}

\footnotetext{
${ }^{1}$ Research Fellow at the Institute of International Politics and Economics, Belgrade, Serbia. E-mail: milos.petrovic@diplomacy.bg.ac.rs

The paper presents the findings of a study developed as part of the research project entitled 'Serbia and challenges in international relations in 2021', financed by the Ministry of Education, Science, and Technological Development of the Republic of Serbia, and conducted by the Institute of International Politics and Economics, Belgrade.
} 
transatlantic privileged relations, which would also reflect on Germany, whose foreign policy is deep-seated in international integrative processes.

Keywords: Germany, the US, integrative processes, Trump, bilateralism, sovereignty, partnership.

\section{INTRODUCTION}

Since the mid-20 ${ }^{\text {th }}$ century onwards, relations between the United States of America (USA) and the Federal Republic of Germany (FRG) have been almost inextricably intertwined with the broader integrative initiatives. The US actively encouraged the evolution of integrative processes in Europe through NATO and European Communities, which also included the FRG and was beneficial for that country's post-war international 'rehabilitation' (Rappaport, 1981, pp. 121-122; Smith, 1995, p. 1). For the US, partnership with Germany represented a part of a larger change of its external policy, which aimed to establish partnerships directed against the Soviet threat (Schwartz, 1995, p. 554). Likewise, the US leadership believed that the inclusion of the FRG into integrative processes would contribute to its postwar stabilization and pacification (Rappaport, 1981, p. 122). The dissolution of the socialist system across Central and Eastern Europe (CEE) which ensued after 1989 was decisive for the FRG on two grounds: firstly, it facilitated the decades-long goal of national reunification, and secondly, it marked the triumph of the 'Western' liberal political and economic model in Europe's heartland. Likewise, the absorption of the former German Democratic Republic into the FRG (in the further text also: Germany) also led to its inclusion in numerous international processes.

Reunited Germany emerged as the EC's leading economic power with around $30 \%$ of its GDP, containing also the bloc's largest population, skilled and equipped military force, and a strong national currency (Smith, 1995, pp. 1-2). Drawing from its recent national history and in congruence with the US, the FRG advocated the European Union (EU) and North Atlantic Treaty Alliance (NATO) enlargements. Although diverging stances towards international military campaigns at times burdened the trans-Atlantic relations, the two countries remained committed to maintaining and advancing their cooperation. There are also views that the interventions across the Middle East also served as a learning experience for the US decision-makers to commence putting greater effort to engage European support, in order to secure more favourable outcomes (Pawlak, 2011, p. 68). The reluctance of nations like Germany to participate in the 'War on Terror' also coincided with the 
growingly autonomous awareness of the expanding EU. Ambition towards a more influential and 'ever closer union' required advancing the strategic cooperation between Germany and France, which has for decades constituted a cornerstone of Berlin's foreign policy, along with the European and transatlantic integration processes (Mahncke, 2011, pp. 85-86, 90). Nevertheless, the US-German cooperation was challenged on numerous occasions during the past years (from the 'War on Terror', through complicated relations between the EU and Russia during the Caucasus and Ukrainian crises, to the Brexit process and, finally, the lack of affinity of US President Trump towards preservation of privileged transatlantic partnership). ${ }^{2}$

As part of the aforementioned context, this paper aims to analyse the growingly challenging political relationship between Germany and the US during the presidency of Mr. Donald Trump. The first research question how has the US-German partnership evolved since the mid-20 th century onwards, introduces the topic of the two countries' political cooperation, interpreting it in the recent historical context. As for the second question, it builds upon the first and considers which aspects of the US-German cooperation were the most affected during the administration of President Trump. The author identifies several aspects of political dissension between the two countries, ranging from diverging perspectives regarding the role of international organizations and initiatives, over political and ideological differences and deviating narratives, to trade and bilateral dissonances. The argumentation was also analysed through theoretical underpinnings, primarily the realist approach, combined with the historical perspective, to place contemporary developments in the context of a broader evolution of the US-German cooperation.

\section{PARTNERSHIP FORGED DURING THE COLD WAR}

'Foreign policy sets the limits to the possibilities of German economic and social policy.'3

Following the demise of the Nazi dictatorship, the territory of contemporary Germany found itself in ruins, politically and otherwise

\footnotetext{
2 Some additional author's research which also addresses the domain of US foreign policy include: Petrović, 2019; Petrović, 2020, pp. 532-565.

${ }^{3}$ Post-war social-democrat Kurt Schumacher, criticizing the 'pro-American' decision-making of the Adenauer cabinet (Schwartz, 1995, p. 561)
} 
estranged from neighbours and divided among the Allied powers. By 1949, tensions between the two contending superpowers, the USSR and the US, have gradually solidified the separation into the two distinct blocs. The border between the First and the Second World went through Germany and was expressed through the existence of the two German states: the Federal Republic of Germany in the west and, to the east, the German Democratic Republic. These territories assumed the role of the political battleground throughout the Cold War.

The absorption of the FRG into the Atlantic community represented one of the foremost US political achievements during the second part of the $20^{\text {th }}$ century (Schwartz, 1995, p. 549). Continuous US support to the international 'rehabilitation' of the FRG has been decisive, including its contribution to overcoming the past disputes with France, as an imperative for broader integrative processes in Western Europe (Rappaport, 1981, p. 141). Multifaceted US assistance to the FRG consisted of support towards the establishment of the democratic system and sustaining the claim for national reunification, economic aid through the European Recovery Program (also known as the Marshall plan), and closer security bonds through the NATO and maintenance of the largest contingent of US troops in Europe.

However, the integration of the FRG into the 'Western' political community was occasionally also marked by suspicion. Whereas some nonGerman experts contemplated that US support could reignite German nationalist behaviour and inevitably lead to its political dominance, some German analysts questioned the dedication of US partners to the German reunification goal (Schwartz, 1995, p. 550). The latter proved to be unfounded, having in mind the unequivocal support of the US administration of George Herbert Walker Bush to unification efforts and his close cooperation in that regard with Chancellor Helmut Kohl (Casdorff, 2018).

US support to the FRG needs to be considered in the context of the Cold War rivalry in Europe against the USSR. According to Thomas Schwarz, closer US-German cooperation also contributed to the deepening of the Cold War anxiety and augmentation of the security dilemma (Schwartz, 1995, p. 550). Decades of the Cold War antagonisms largely unfolded over the borders of two Germanies. The Berlin citizens witnessed several major international events: the Soviet-led Blockade (1948-1949), the construction of the Wall (1961), the fall of the Wall (1989), the acceding to the Federal Republic of Germany (1990) and the retrieval of the capital-city-status. Following a momentous Cold-War-event - the erection of the Berlin Wall, US President John F. Kennedy delivered one of the most notable political 
speeches, expressing solidarity with inhabitants of West Berlin: 'All free men, wherever they may live, are citizens of Berlin, and, therefore, as a free man, I take pride in the words "Ich bin ein Berliner"' (Eichhoff, 1993, p. 74).

As part of its strategy of strengthening Western Europe against USSR expansion, the US supported the reconciliation efforts between the FRG and France, which was occasionally ambivalent towards such steps (Hitchcock, 1997, pp. 625-627; Lynch, 2004, pp. 117-118). French cooperation was additionally encouraged by substantial aid through the European Recovery Program, aimed at post-war reconstruction, developing and upgrading industrial performance, fostering closer economic relations, etc. (Hitchcock, 1997, p. 612). The economic and political stabilization which ensued as a result of US-backed policies also provided a favourable context for the realization of Jean Monnet's political project, which was supported by the French foreign minister Robert Schuman and the FRG Chancellor, Konrad Adenauer. The establishment of the European Coal and Steel Community in 1950, according to Mr. Schuman, entailed a noble purpose to 'make the conflict between nations of Europe not simply unthinkable, but materially impossible' (Hitchcock, 1997, p. 603). The signing of the Treaty establishing the European Economic Community in Rome ensued in 1957 (Drake \& Reynolds, 2017, p. 111). Likewise, the intensification of French-German cooperation resulted in the Élysée Treaty of friendship, signed by President Charles de Gaulle and Chancellor Konrad Adenauer in 1963, which still represents the foundation of their strategic coordination. ${ }^{4}$

Even following the dissolution of the Warsaw Treaty Organization and the subsequent reunification, the US-German strategic interests remained largely corresponding. Even though the demise of the Soviet military threat significantly reduced Germany's dependence on US patronage, cooperation through NATO still remained as one of Berlin's priorities (Mahncke, 2009, p. 81). Despite early signs of trans-Atlantic dissonance appeared as the newly-proclaimed EU began to gradually develop its more autonomous identity, its ambitions turned out to be unrealistic already during the period of the Yugoslav wars, for which it failed to develop its own peace strategy. Also, this period was marked by a rare example of reunited Germany's onesided action, which, unsatisfied with the EU's prolonged response, unilaterally recognized the independence of Slovenia and Croatia, thus setting an example for other countries to 'jump on the same bandwagon'.

${ }^{4}$ Treaty between the French Republic and the Federal Republic of Germany on French-German cooperation (22 January 1963). 
However, as the conflict escalated further, eventually the US intervened, highlighting the EU's strategic deficiencies (Marolov, 2012, p. 15). The lack of a common EU approach was, therefore, 'sobering' for Germany in two ways: firstly, it encouraged the FRG to reconsider its own national interest and its ability to act independently when deemed necessary, and secondly, to focus on supporting a more unified and strategically autonomous EU, even if it implied some distancing from the US (Smith, 1995, p. 19). In the context of the 'War on Terror', the US expected a greater military and political engagement from its EU and NATO partners, whereas Germany considered the armed forces to be insufficient for conflict resolution in countries like Afghanistan (Mahncke, 2009, p. 87; Rühle, 2009, pp. 2-5). Moreover, Germany looked back upon its conflict past to pursue a more restrictive approach to interventionist projects and accentuate the necessity for peaceful conflict resolution whenever possible in international affairs, including within NATO (Snyder, 2011, p. 182). The transatlantic rift over the Iraq intervention exposed the reluctance of European partners to align with the US 'by default' (De Vasconselos, 2011, p. 5). This especially applies to Germany, which, although it remained anchored to NATO and EU strategies, has also been attempting to lead a somewhat more autonomous foreign policy during the past two decades, although with mixed results (Pribićević \& Miljuš, 2012, p. 406).

As Dieter Mahncke noted: 'While the United States has consistently called for a more active Europe, Washington time and again has displayed an ambivalent attitude towards European projects, concerned about what effects this might have on NATO and concerned about maintaining American leadership' (Mahncke, 2009, p. 89). The occasionally ambivalent relations could have resulted from the earlier US perception of the European integration project as a mode to strengthen the continent against a foreign threat, rather than an instrument to challenge the American political and economic hegemony (Rappaport, 1981, p. 121).

Differences in opinion occasionally placed a strain on otherwise advanced strategic transatlantic cooperation during the past several decades. However, following the 2016 election victory of the Republican candidate Mr. Donald Trump, who had no previous government service experience, the otherwise advanced transatlantic cooperation commenced to be challenging in numerous domains. The 'Trump era' was marked by changes and discontinuity in various aspects of US-German cooperation compared to the previous period. 


\title{
THE TRUMP PRESIDENCY: TESTING THE PARTNERSHIP'S LIMITS
}

\begin{abstract}
'The countries we are defending must pay for the cost of this defence, and if not, the US must be prepared to let these countries defend themselves.

We have no choice. ${ }^{5}$
\end{abstract}

In January 2017, during a joint press conference with the British Prime Minister Theresa May at the White House, the recently inaugurated US President Donald Trump praised the pro-Brexit vote as a 'wonderful thing' and a 'blessing for the world' (Langlois, 2018, p. 13). These words sharply contrasted with the statement of Mr. Barack Obama, who during his own visit to London only several months earlier underlined that 'no man was an island ... even an island as beautiful as this', implying that the United Kingdom's possibilities would be reduced in case of withdrawal from the European Union (Schuppe, 2016). Mr. Trump's support for Brexit, including the option of a 'no-deal' withdrawal, raised concerns in Germany regarding the President's general stance towards the European partners (Sandle \& Addison, 2019).

President Trump also expressed disregard for the history of the European integration as a peace process by stating his opinion that the ' $\mathrm{EU}$ was formed, partially, to beat the US on trade', adding that to him 'it didn't matter whether the EU remained together' or dissolved (Langlois, 2018, p. 22). Mr. Trump also labelled the EU as an instrument in the hands of Germany (Lopandić \& Bogdanović, 2017, p. 2). 'European partners' have never before witnessed such a high level of criticism from their American counterpart (Langlois, 2018, p. 24). Likewise, Mr. Trump's presidency appeared to be dissociated from a predictable political ideology but rather marked by a lack or absence of a coherent strategy (Trapara, 2017, pp. 6264). President Trump time and again displayed a lack of interest in the established facts, historical background and activities that could shape a consistent plan (Sloan, 2018, p. 222). Trump's governing principles included protectionist and anti-globalist tendencies, with reduced interest for past historical experiences and a lack of predictable and transparent cost-benefit logic in certain domains (Ninkovich, 2018, p. 400). His governance encapsulated the phenomena such as populism, nativism (a narrower form of nationalism), authoritarianism, but also Christian Evangelical narratives

${ }^{5}$ Statement of the presidential candidate Donald Trump in 2016 (Sloan, 2017, p. 226). 
and interpretations (Alder \& Schäublin, 2020, pp. 1-2; KuvekalovićStamatović, 2019, p. 40). The president's aversion towards a more structured and traditional political approach, coupled with a largely undiplomatic manner of communication represented a political discontinuity and gradually raised concern in Germany and elsewhere in Europe regarding further US commitment to their partnership.

The disinclination of presidential candidate Mr. Trump towards multilateral organizations and traditional partnerships manifested through the designation of NATO as an 'obsolete' entity that required restructuring and additional emphasis on fighting terrorism (Sloan, 2018, p. 225). Once in power, Mr. Trump maintained his narrative that US allies from NATO should be more committed to the joint mission, including the financial aspect. The first meeting with Chancellor Angela Merkel in March 2017 was characterized as unusual, as depicted not only by the absence of a handshake but also in President Trump's rhetoric that 'NATO allies needed to pay their fair share for the cost of defence', and that their alleged debt was 'very unfair to the United States' (Sloan, 2018, p. 228). The alleged debt the US President was mentioning actually represented a German defence expenditure which during the period 2014-2019 amounted to below 1.5\%, comparing to the NATO-targeted 2\% of GDP (NATO, 2019, p. 3).

Nevertheless, it is noteworthy that at the time the vast majority of NATO member-states, including not only Germany but France, Italy, and others, did not comply with that requirement, although that somewhat improved towards 2020 (NATO, 2019, p. 3). The first international participation of Mr. Trump in NATO and G7 Summit in Europe in spring 2017 was also marked by his criticism over the partners' unsatisfactory defence spending and a call for NATO to formally enter the anti-ISIS coalition (which it did, although its member-states already participated bilaterally) (Sloan, 2018, p. 231). Mr. Trump also used the opportunity to declare that the German car industry functioned 'very badly' and damaging towards the US, which -among other things - led Chancellor Merkel to state that 'the days when Europe could rely on others (was) over to a certain extent' (Sloan, 2018, p. 231). When referring to 'Europe' in her statement, the Chancellor also implied 'Germany', having in mind the centrality of the European and transatlantic integrative processes for that country. And vice-versa: when President Trump was denouncing European partnerships, even when not singled out, Germany emerged as the most likely subject of criticism (Franke \& Leonard, 2017). Germany ceased to be treated as the primary US partner in continental Europe during Mr. Trump's mandate. 
There are several aspects for consideration in the context of the severance of the transatlantic political partnership during Mr. Trump's presidency, which particularly affected Germany as one of the leading EU and NATO members.

Firstly, during Mr. Trump's presidency, the perceptions of integrative processes and the role of international organizations diverged between the partners. As addressed earlier, through the virtue of international integrative processes supported by the United States, the FRG 'rehabilitated' its international reputation, overhauled its economy, political system and improved its relations with neighbours and wartime opponents. Apart from its international reintegration, active participation in a variety of transnational organizations also served as a mode to exert German influence abroad, in a structured way which would be clearly dissociated with its wartime reputation (Snyder, 2011, pp. 181-182). The US confrontation with the EU during the Trump mandate had several critical points, ranging from the abandonment of the Trans Atlantic Trade and Investment Partnership ('TTIP', negotiated with Mr. Obama's administration), to supporting the unilateral UK activities during the Brexit process (against the EU), to a disagreement regarding the functioning of global initiatives (as portrayed by the abandoning of the United Nations agencies like UNESCO or the World Health Organization (WHO) at a sensitive time during the 2020 CoVid-19 pandemic). The TTIP was envisaged to further liberalise trade rules in a variety of domains in the northern transatlantic region (which already accounts for one half of the global production), and growingly influence the trade globalization processes, which would especially benefit the German corporations' exports (the US being the most valuable market and the most attractive 'third country' for German investments) (Auswärtiges Amt, 2020).

Repudiation of further US-German (and EU) coordination in international initiatives and processes deeply affected the dynamics of their political cooperation and economic relations during the administration of Donald Trump. These developments directed Germany and the EU towards a more autonomous action in international affairs while attempting to maintain as much traditionally privileged transatlantic cooperation as possible.

Secondly, the political narrative between the transatlantic partners has diverged. On the one hand, democratic concepts in the domains of governance, human rights, combined with liberal economic norms and integrative processes, have propelled not only the European but also other 
transatlantic and broader international integration processes and ideas. Other important aspects, such as climate change and migrations remained the political priorities of the EU and Germany. However, Mr. Trump's administration formally distanced from such notions, preferring the sovereignist approach which sometimes resembled policies of interwar administrations that opted to be less engaged in international affairs (Ninkovich, 2018, p. 398).

Unlike any president since the end of the Cold War, Mr. Trump's narrative reflected deep distrust towards decades of privileged cooperation with European partners. His anti-immigrant rhetoric, previously used in the context of the US-Mexican border issue, was applied in the context of the European migrant crisis, serving as additional reasoning for Brexit and for public dismissal of Chancellor Merkel's stance during that event. According to President Trump, the migrants from the Middle East and Africa have 'strongly and violently changed European culture' and 'Europe should not have allowed them in', adding that Germans were 'turning against their leadership' and making analogies between migrations and alleged increased crime rates in that country (Stone, 2018).

Apart from enthusiastically supporting the border fence built in Hungary, designed to halt immigration, President Trump also deepened relations with other 'sovereignist' EU countries like Poland, which was criticized by international bodies over its conservative trends in the domains of rule of law and the judiciary (Ágh, 2018, p. 33). Apart from the visa-waiver for the United States, Mr. Trump has announced the deployment of NATO troops in Poland, as well as investments into several strategic domains (White House, 2019). These actions should not be interpreted solely as Mr. Donald Trump's support to likely-minded leaderships in Europe, but also in the context of encouraging political and other divisions within the EU, which the US president perceived as a trade rival, and perhaps even a political opponent. The weakening of the EU in that regard would also weaken Germany as the bloc's export hub.

Thirdly, the US-German cooperation was also affected in bilateral terms, due to strategic and trade reasons. One of the largest causes of contention, apart from the insufficient NATO defence expenditure, was the construction of the Nord Stream 2 gas pipeline across the Baltic Sea, linking Russia and Germany. Although the project is multinational, Germany as the continent's leading energy consumer would be the most affected in case of its delay or non-realization. Perhaps unsurprisingly, according to a 2020 poll, Germans largely supported the completion of the pipeline with Russia, despite the 
two countries' troublesome relations. ${ }^{6}$ German participation in the Nord Stream 2 project actually represented another (infrequently seen) example of that country's ability to act independently in securing its national interest, even if it implied aggravating the neighbouring countries, as well as its traditional transatlantic partner.

Large geopolitical controversies have surrounded the Nord Stream 2 project, especially a perceived intention to bypass Ukraine as an unreliable transport country (Noël, 2019, p. 90; Šekarić, 2020, p. 121). This view is shared by Ukraine's Baltic neighbours, objecting to the project, which might further increase Russian influence and marginalize EU's eastern parts. German relations with Russia in the context of Nord Stream 2 have developed into a divisive topic both within the EU and in transatlantic relations. Whereas President Trump condemned the German-Russian energy cooperation at the NATO Summit in 2018, the Polish authorities compared it to the 'Molotov-Ribbentrop' pact, directed against a European country (Noël, 2019, p. 92). The Trump administration announced sanctions for constructors and other participants in the Nord Stream 2, denouncing the project not only because of worsened relations with Russia but also due to increased production of natural gas, which the US intends to distribute to Europe on a larger scale (Dezem, 2020). However, the European Commission's official stance in the context of the US embargo was that many EU companies have been engaged in the Nord Stream 2 project, and their sanctioning was not being considered provided that they functioned in accordance with the acquis (McDougall, Reisinger \& Greenwood, 2020). Apart from Russia, the US also scrutinized the EU's trade relations with China, which has officially been recognized as a rival power. Germany and other EU countries have been pressured to side with the US over China in trade disputes (Kärnfelt, 2020). US protectionist logic served a dual purpose: to deter European partners from deepening cooperation with China and to influence them to grant trade concessions.

As elaborated above, under the Trump administration Germany came under criticism in numerous aspects, ranging from the denunciation of its export-oriented economy, over disapproving the political decisions and beliefs of its decision-makers, to questioning the international role of German-supported integrative processes and initiatives. These

\footnotetext{
${ }^{6}$ Based on the results published by Civey on a representative sample of 5.090 Germans in 2020, 55.2\% of the respondents opted in favour of putting into operation the Nord Stream 2 pipeline (Civey, 2020).
} 
disconfirming US activities challenged the German institutions' intentions to maintain the scope and functioning of their strategic partnership, as well as their ability to cooperate through other organizations.

\section{THEORETICAL CONSIDERATIONS}

'The United States played a central role in the Federal Republic's history, influencing almost every aspect of its development.'

(Schwartz, 1995, p. 550)

The US-FRG political partnership has been in force for over seven decades. The Western European and transatlantic integrative processes, which included Germany, have redesigned the paradigm of international relations, moving its focus away from the security-related aspects towards domains such as human rights and economic cooperation (Schwartz, 1995, pp. 552-553). However, the victory of Mr. Trump under the 'America First' slogan and his untraditional foreign political leadership led to a perception that the new U.S. president would be inclined to radically transform the transatlantic strategic cooperation (Keylor, 2018, p. 322).

This segment analyses the evolution of US-German cooperation through the realist theory, which perceives states as predominant international actors. Throughout the Cold War, two states - the US and the USSR contended over political hegemony in international affairs. For the US, a partnership with the FRG was pivotal in efforts to deter and eventually defeat the Soviet ambitions in Central Europe, primarily through making (West) Germany the economic pillar that anchored and strengthened the European and transatlantic integration processes (Schwartz, 1995, p. 556). The US hegemony in that region was maintained through closer cooperation with Western European countries, just as the Soviet supremacy persisted in Eastern Europe. Both Germany and the US perceived strategic cooperation to be in their national interest. According to the former Chancellor Helmut Kohl, the partnership with the US was of 'existential importance' for the FRG (Schwartz, 1995, p. 555). For the FRG, this cooperation represented a twofold opportunity: to strengthen its international position through the integrative processes, and to advance its claim for national reunification.

For Hans Morgenthau, the concept of owning power should not be reduced solely to military capacities, but also to the influences exerted through political strength (Guzzini, 2018, p. 14). In post-war Europe, the 
'hard power' of American troops contained the potential recurring of German nationalist ambitions and guaranteed predictable development and realization of US strategic goals. However, apart from that, the US also assisted in redesigning the German political and economic system through the Marshall Plan and supporting reconciliation efforts in Western Europe. An economically strong FRG that stationed NATO troops represented a steady deterrent for the expansion of real-socialism westwards, and, after 1989, served as a backbone of the 'Eastern enlargement' processes. Despite some other differences in the foreign policy domain following the 9/11 attacks in the US, both countries remained committed to further evolving their bilateral and multilateral cooperation.

Since 2016, President Trump governed in accordance with the 'America First' slogan. The mentioned catchphrase, however, differentiated from its original use by President Woodrow Wilson to denote his intention to preserve as long as possible US non-involvement in WW1 Europe (Keylor, 2018, p. 322). Apart from focusing primarily on the structural argumentation, political thinkers like Kennet Waltz also noticed a certain relevance of the human nature aspect in international political processes, and indicated potential correlations between the leader's personality and political preferences in foreign policy decision-making (Jervis, 2018, pp. 34). President Trump was an exceptionally distinct political figure, who, unlike his predecessors, did not put a large emphasis on foreign policy elements like traditional partnerships, support to transnational institutions and current international order, increasingly liberal and global international trade, and human rights preservation (Jervis, 2018, p. 4). Trump's policy rather manifested through scepticism towards multilateral initiatives, support to sovereignist and anti-globalist activities. The decreased willingness for multilateral cooperation with Germany and other European partners during the 'Trump era' was even highlighted by political thinkers such as John Mearsheimer and Stephen Walt, who called for 'handing over NATO to Europeans' (Keylor, 2018, p. 325).

However, having in mind that Mr. Trump's disinclination towards a paramount US role in maintaining the current international order was confronted with constraining effects of domestic and international institutions, radical shifts in international order were averted, although some changes definitely occurred. The historical institutionalism explanation suggests that institutional memory represents an important factor in constraining future political and other activities, regardless of whether the decisions are made based on cost-benefit analysis or sometimes even 'by 
default' (Greener, 2005, pp. 62-63). The challenging aspect of Trump's administration was his limited regard for historical understanding and diplomatic history, and affinity for decision-making by 'gut feeling' (Ninkovich, 2018, p. 399). Some even suggest that Mr. Trump was not interested in historical or traditionalist considerations (Langlois, 2018, p. 68). President Trump's tendency towards spontaneity and occasional indifference towards scientific and other facts stood in contrast with the traditional functioning of institutional and other procedures.

Firstly, President Trump aimed to circumvent the institutional and procedural influences in the foreign policy domain when deemed necessary. However, it would not be fair to attribute that tendency solely to Mr. Trump, having in mind that the US Congress' oversight of US foreign policy has been declining for decades (Goldgeier \& Saunders, 2018). Nevertheless, political polarization and the sidelining of US institutions, including its skilled bureaucracy, deepened and intensified during the Trump presidency (Goldgeier \& Saunders, 2018). Despite their authority, institutions are also prone to changes and redesign. In line with the historical institutionalism postulates, the changes might lead future institutional actions to some altered direction. In foreign policy terms, President Trump applied this logic through influencing the institutional functioning (for example, calling for higher NATO expenditures or its greater focus on combating terrorism), and also through withdrawing from agreements, thus further reducing or altering their influence on the implementation of US policies. However, having in mind the extraordinary political influence of the United States, such activities (withdrawal from UNESCO, the WHO, the Paris Agreement (2016), etc.) also affected other international actors, including Germany as one of the leading multilateral actors. Nevertheless, the strength of earlier institutional procedures and arrangements hampered a more radical discontinuance with previous policies and the possibility for enforcing arbitrary decisions. ${ }^{7}$

Secondly, President Trump also resisted institutional procedures by recruiting politically-or-otherwise-close and loyal persons. For instance, Mr. Trump's appointment of Mr. Richard Grenell as US ambassador to Germany resulted in undiplomatic activities like the envoy's criticism over its migrant

\footnotetext{
${ }^{7}$ President Trump's inclination towards averting the institutional procedures was not only present in the foreign policy domain. Namely, during November and December 2020, Mr. Trump also made an unsuccessful attempt to dispute the outcome of 2020 US presidential elections before the relevant institutions and voiced unwillingness to hand over his post to the President-Elect Biden.
} 
and other internal German policies, which made Mr. Grenell an unpopular representative in Berlin (Riecke, 2020). Likewise, some other instances might also include the appointing of Mr. Trump's daughter Ivanka and his sonin-law Jared Kushner for advisory positions in his cabinet (Blake, 2019). During his mandate, Mr. Trump also made over 200 judicial lifetime appointments (constituting one-quarter of the entire federal judiciary), out of whom a majority of conservative candidates, which was sometimes interpreted as an intent to secure a more enduring Republican influence in the polarized US institutions (Wise, 2020).

As mentioned earlier, President Trump called for modifications of numerous agreements with partners (for example, NAFTA). However, the depiction of Mr. Trump's sovereignism is that he almost exclusively sought to improve the apparent damaging parts for the US, while remaining disinterested to advance those sections which could have been beneficial to other countries (Jervis, 2018, p. 5). Although the checks and balances, accompanied by strong institutional procedures, neutralized the possibility for fundamental institutional changes, Mr. Trump's modus operandi in political practice was more unilateral and occasionally without regard to previous experiences and partnerships. As noted by Robert Jervis: 'In questioning the value of America's alliances, at least as they are presently structured, and in doubting the value of other multilateral institutions, Trump has articulated a narrower conception of the American national interest than that held by any previous president' (Jervis, 2018, p. 4).

In a somewhat realistic manner, President Trump abstained from conducting foreign interventionist campaigns and favoured the reduction or withdrawal of US troops from countries like Afghanistan, Somalia and Syria (Jervis, 2018, p. 5). Apart from the non-interventionism, the US governance during the 'Trump era' considerably adhered to the concepts such as sovereignty and the centrality of the state (Stirk, 2015, p. 5). ${ }^{8}$ Mr. Trump's fondness towards more 'Westphalian' interstate relations might derive from the president's impression that the US benefits could have been maximized through individual agreements rather than multilateral cooperation. His administration's aversion from multilateral initiatives was somewhat counterbalanced by the greater emphasis on some interstate relations. ${ }^{9}$ For

\footnotetext{
${ }^{8}$ For theoretical considerations regarding the notions of state power, sovereignty and political decision-making, consult: Stirk, 2015, pp. 1-15.

${ }^{9}$ For example, President Trump attempted to 'reset' relations with North Korea, advance cooperation with the UK, Poland and other countries.
} 
instance, Mr. Trump had advocated a 'massive new trade deal' with the UK after Brexit which could have been 'far bigger and more lucrative than any deal that could be made with the EU (Gallardo, 2019). The disinclination towards multilateral diplomacy and affinity towards bilateralism might be considered retrogressive, having in mind not only the globalist world order but also the decades-long US efforts in making the world such. The US president's rhetoric and policies significantly diverged from the liberal and democratic peace postulates, which favoured further deepening of multilateral alliances as a means to strengthen the US global role. Mr. Trump's administration also diverged from international priorities like the fight against climate change (exemplified by the withdrawal from the Paris Agreement), trade freedoms (suspension of regional initiatives such as the TTIP) and questioning further NATO participation (including its 'solidarity clause' in case of external threats). The foreign policy paradigm shift during the Trump administration diverged from the interests of Germany as one of the closest US partners, which reflected negatively on their relations.

\section{CONCLUSION}

Already in the mid-1990s, long before the inauguration of Mr. Trump as US President, Prof. Thomas Schwartz questioned further perspectives of the US-Germany relations, deliberating on whether the two countries would retain their partnership and cooperation in international affairs, or would they rather diverge towards different goals, which would likely encourage unilateralism and instability (Schwartz, 1995, p. 568). Several decades later, the latter occurred, with Mr. Trump's administration drifting apart from the strategic partnership with Germany.

Apart from the sovereignist narrative, President Trump's disinclination towards the integrative processes and the role of international organizations, combined with protectionist and anti-multilateral measures and preference towards bilateralism, signalled a paradigm shift in transatlantic and USGerman relations. Mr. Trump's inclination towards bilateralism represented a somewhat anachronistic perception about states constituting the primary influential international actors, which was analysed through a realist approach. On the other hand, organizations like NATO have endured Mr. Trump's criticism while providing enough room for cooperation. Despite the challenges and perhaps the lowest ever interest in organizations like NATO by an incumbent US president, the Alliance was territorially 
expanded to encompass new countries in the Western Balkans, and member-states like Germany pledged to increase their defence spending.

Arguments presented in this paper lead to a finding that German policies were criticized on several levels during Mr. Trump's presidency, ranging from disapproving its trade surplus, over questioning official political measures in various domains (the migrant crisis, energy projects, below-target defence expenditures), to broader discontent regarding the development of international processes. These activities were not conducive for maintaining the strength and direction of the US-German strategic partnership, nor have they been helpful to their cooperation within international initiatives. The CoVid-19 pandemic and the sudden shutdown of US borders for the Schengen area countries illustrated the lower degree of solidarity and transatlantic cooperation. As an unnamed European diplomat pessimistically noted: 'We feel there should have been cooperation rather than action that targets one continent' (BBC, 2020).

The unprecedented challenges posed by the CoVid-19 pandemic and the Brexit process, coupled with different layers of bilateral and multilateral dissonances in relations with the US, turned Germany's Presidency of the Council of the EU in 2020 into a daunting task. The above-quoted statement from a European diplomat might have also reflected the failed hopes of the German government for more solidarity with the US partner. Unsurprisingly, it was during the aforementioned Germany's Presidency that the Council of the EU adopted its conclusions on EU-USA relations, reaffirming the strategic importance of the transatlantic partnership. ${ }^{10}$ The 'timing' was very important, having also in mind the announced withdrawal of Ms. Angela Merkel from politics following the completion of her fourth Chancellorship in 2021. As the President-Elect, Mr. Joseph Biden called for the restoration of partnership with European partners, it is expected that the US and German leaderships begin to gradually tackle the previously accumulated disagreements and challenges, which due to their complexity and multi-dimensionality, might make the process more challenging than originally envisaged.

${ }^{10}$ Council of the European Union, 2020, 7 December 2020, Council conclusions on European Union - United States relations. 


\section{REFERENCES}

Ágh, A. (2018). Decline of democracy in the ECE and the core-periphery divide: rule of law conflicts of Poland and Hungary with the EU, Journal of Comparative Politics, 11(2), pp. 31-35.

Alder, C. \& Schäublin, E. (2020). US Evangelicals: From Prophecy to Policy, Policy Perspectives, 8(11), pp. 1-2.

Auswärtiges Amt. (2020). Towards a transatlantic economic agreement the Transatlantic Trade and Investment Partnership (TTIP). (2020), retrieved from https://www.auswaertiges-amt.de/en/aussenpolitik/ ttip/259628. Accessed 11 November 2020.

BBC (2020). Coronavirus: EU condemns Trump travel ban on 26 European countries. (2020, March 12), retrieved from https://www.bbc.com/ news/world-us-canada-51857462. Accessed 20 December 2020.

Blake, A. (2019, March 12). Ivanka Trump and Jared Kushner are a case study in why nepotism is problematic. Washington Post, retrieved from https:/ / www.washingtonpost.com/politics/2019/03/12/ivankatrump-jared-kushner-are-case-study-why-nepotism-is-problematic/. Accessed 1 December 2020.

Casdorff, S. A. (2018, December 2). Wie George H. W. Bush Schirmherr der Einheit wurde. Der Tagesspiegel, retrieved from https://www.tages spiegel.de/politik/verstorbener-ex-us-praesident-wie-george-h-wbush-schirmherr-der-einheit-wurde/23706984.html. Accessed 20 December 2020.

Civey. (2020). Sollte die Gaspipeline „Nord Stream 2“ trotz der aktuellen Konflikte mit Russland in Betrieb gehen?. (2020), retrieved from https:/ / civey.com/ umfragen/7280/ sollte-die-gaspipeline-nordstream-2-trotz-der-aktuellen-konflikte-mit-russland-in-betrieb-gehen. Accessed 5 December 2020.

Council of the European Union. (2020). Council conclusions on European Union - United States relations, 7 December (Council of the European Union, Brussels).

De Vasconcelos, Á. (2011). [Introduction]. In Á. De Vasconcelos (Ed.), The agenda for the EU-US strategic partnership (pp. 5-6). Paris, European Union Institute for Security Studies.

Dezem, V. (2020, November 25). European Companies Stick to Nord Stream 2 Even Amid U.S. Furor, retrieved from https:// www.bloomberg.com/ 
news/articles/2020-11-25/euroean-companies-stick-to-nord-stream-2even-amid-u-s-furor. Accessed 5 December 2020.

Drake, H. \& Reynolds, C. (2017). Sixty years on: France and Europe from the Treaty of Rome to the 2017 elections, Modern $\mathcal{E}$ Contemporary France, 25(2), 111-116.

Eichhoff, J. (1993). "Ich bin ein Berliner": A History and a Linguistic Clarification, Monatshefte, 85(1), pp. 74-75.

Franke U. E. \& Leonard, M. (2017, May 3). Germany, not China, will be Donald Trump's enemy number one, retrieved from https:// ecfr.eu/article/commentary_germany_not_china_will_be_donald_tru mps_enemy_7282/. Accessed 10 December 2020.

Gallardo, C. (2019, December 13). Donald Trump: Tory victory opens door to 'massive' UK-US trade deal. Politico, retrieved from https://www.politico.eu/article/donald-trump-tory-victory-opensdoor-to-massive-uk-us-trade-deal/. Accessed 1 December 2020.

Goldgeier, J. \& Saunders, E. N. (2018, September/October). The Unconstrained Presidency. Foreign Affairs, retrieved from https:/ / www.foreignaffairs.com/articles/2018-08-13/unconstrainedpresidency. Accessed 16 November 2020.

Greener, I. (2005). The Potential of Path Dependence in Political Studies. Politics, 25(1), pp. 62-72

Guzzini, S. (2018). Hans. J. Morgenthau and the Three Purposes of Power. Danish Institute for International Studies Working Paper, 4, pp. 14-15.

Hitchcock, W. (1997). France, The Western Alliance and the Origins of the Schuman Plan 1948-1950, Diplomatic History, 21(4), pp. 603-610.

Jervis, R. (2018). President Trump and international relations theory, in: R. Jervis, F. J. Gavin, J. Rovner, D. N. Lambrosse \& G. Fuji (Eds.), Chaos in the Liberal Order - The Trump Presidency and International Politics in the Twenty-First (pp. 1-5). New York, Columbia University Press.

Kärnfelt, M. (2020, May 25). Europe's position in the US-China trade conflict: It's the exports, stupid, retrieved from https://merics.org/en/shortanalysis/europes-position-us-china-trade-conflict-its-exports-stupid Maximilian. Accessed 20 November 2020.

Keylor, W. R. (2018). The future of Atlantic alliance under Donald Trump, in: R. Jervis, F. J. Gavin, J. Rovner, D. N. Lambrosse \& G. Fuji (Eds.), Chaos in the Liberal Order - The Trump Presidency and International Politics in the Twenty-First (pp. 322-325). New York, Columbia University Press. 
Kuvekalović-Stamatović, J. (2019). Trampizam kao Hantingtonov politikos budućnosti i simptom globalne civilizacijske panike [Trumpism as Huntington's politicos of the future and a symptom of global civilization panic], in: V. Trapara, A. Jazic (Eds.), Kontroverze spoljne politike SAD $i$ međunarodnih odnosa u Trampovoj eri, (p. 40). Beograd, Institut za međunarodnu politiku i privredu.

Langlois, L. (2018). Trump, Brexit and the Transatlantic Relationship: The New Paradigms of the Trump Era, Revue Lisa, XVI (2), pp. 13-22.

Lopandić, D. \& Bodganović, B. (2017). Evropska unija i Trampova Amerika - Novi "stres test" izdržljivosti transatlanskog savezništva [The European Union and Trump's America - A new "stress test" of the endurance of the transatlantic alliance], Evropski izazovi, pp. 2-4.

Lynch, F. M. (2004). France and European Integration: From the Schuman Plan to Economic and Monetary Union, Contemporary European History, 13(1), pp. 117-121.

Mahncke, D. (2009). The United States, Germany and France: Balancing Transatlantic Relations, The British Journal of Politics and International Relations, 11, pp. 79-85.

Marolov, D. (2012). The Policy of the USA and EU towards the Disintegration of Yugoslavia, International Journal of Social Science Tomorrow, 1(2), p. 15.

McDougall, K, Reisinger, S. H \& Greenwood, S. (2020, November 6). Update on US sanctions in respect of Nord Stream 2 and TurkStream pipelines, retrieved from https://www.nortonrosefulbright.com/en/knowledge/publications/5 42bab55/us-house-approves-nord-stream-2-and-turkstream-sanctionsadoption-appears-likely. Accessed 5 December 2020.

NATO (2019). Defence Expenditure of NATO Countries (2013-2019). (2019, November 29), retrieved from https://www.nato.int/nato_static fl2014/assets/pdf/pdf_2019_11/20191129_pr-2019-123-en.pdf. Accessed 10 November 2020.

Ninkovich, F. (2018). Trumpism, history and the future of US foreign relations, in: R. Jervis, F. J. Gavin, J. Rovner, D. N. Lambrosse \& G. Fuji (Eds.), Chaos in the Liberal Order - The Trump Presidency and International Politics in the Twenty-First (pp.398-402). New York, Columbia University Press.

Noël, P. (2019). Nord Stream II and Europe's Strategic Autonomy, Survival, 61(6), pp. 89-95. 
Pawlak, P. (2011). [Conclusion]. In: Á. De Vasconcelos (Ed.), The Agenda for the EU-US strategic partnership (pp. 68-70). Paris, European Union Institute for Security Studies.

Petrović, M. (2019). Nastanak ukrajinske krize: od političke iluzije Evropske unije do bitke za postsovjetsku Evropu. Belgrade, Institute of International Politics and Economics.

Petrović, M. (2020). Bregzit kao ishod ambivalentne britanske politike prema evropskoj integraciji, Međunarodni problemi, LXXII (3), pp. 532-565.

Poushter, J, Mordecai, M. (2020). Americans and Germans differ in their views of each other and the world. Washington, Pew Research Center.

Pribićević, O \& Miljuš, B. (2012). Izazovi i perspektive nemačke spoljne politike [Challenges and Perspectives of German Foreign Policy]. Međunarodni problemi, LXIV (4), pp. 403-424;

Rappaport, A. (1981). The United States and European Integration: The First Phase, Diplomatic History, 5(2), pp. 121-149.

Riecke, T. (2020, February 20). Der unbeliebte US-Botschafter verlässt Berlin - aber nicht für immer. Handelsblatt, retrieved from https://www. handelsblatt.com/politik/international/richard-grenell-der-unbeliebteus-botschafter-verlaesst-berlin-aber-nicht-fuer-immer / 25565422. html?ticket=ST-16716294-C2P2w6TCLMXglAsBFVwv-ap2._Accessed 20 November 2020.

Rühle, M. (2009). Afghanistan, Deutschland und die NATO, Sicherheit und Frieden, 27(1), pp. 2-5.

Sandle, P. \& Addison, S. (2019, June 2). Trump tells Britain to 'walk away' if EU does not yield on Brexit, retrieved from https://de.reuters.com/ article/uk-usa-britain-trump/trump-tells-britain-to-walk-away-if-eudoes-not-yield-on-brexit-idUSKCN1T23GR. Accessed 15 November 2020.

Schuppe, J. (2016, April 22). Obama Warns Britain on EU ‘Brexit’ Vote: 'No Man Is an Island', retrieved from https://www.nbcnews.com/ storyline/brexit-referendum/obama-warns-britain-eu-brexit-vote-noman-island-n560551. Accessed 15 November 2020.

Schwartz, T.A. (1995). The United States and Germany after 1945: Alliances, Transnational Relations, and the Legacy of the Cold War, Diplomatic History, 19(4), pp. 549-568.

Šekarić, N. (2020). Evropska energetska bezbednost: slučaj Severnog toka 2 [European Energy Security: the case of Nord Stream 2], Medunarodna politika, LXXI (1779-80), pp. 121-122. 
Sloan, S. R. (2018). Donald Trump and NATO: Historic Alliance Meets Ahistoric President, in: R. Jervis, F. J. Gavin, J. Rovner, D. N. Lambrosse \& G. Fuji (Eds.), Chaos in the Liberal Order - The Trump Presidency and International Politics in the Twenty-First Century (pp. 221-231). New York, Columbia University Press.

Smith, M. (1995). The Limits of Leadership: Germany and the EMS/ Yugoslavian Crises [lecture], retrieved from http:/ / aei.pitt.edu/ 7018/. Accessed 20 December 2020.

Snyder, E. (2011). Possibilities for Peace: Germany's Transformation of a Culture of War, Journal of Sociology and Social Welfare, XXXVIII (2), pp. 181-184.

Stirk, P. (2015). The Concept of the State in International Relations, in: R. Schuett \& P. M. R. Stirk (Eds.) The Concept of the State in International Relations: Philosophy, Sovereignty, Cosmopolitanism (pp. 5-7). Edinburgh, Edinburgh University Press.

Stone, J. (2018, June 18). Trump attacks Angela Merkel for giving sanctuary to refugees. The Independent, retrieved from https:/ / www.independent. co.uk/news/world/europe/trump-angela-merkel-germany-refugeessanctuary-twitter-us-immigration-a8404501.html. Accessed 10 December 2020.

Trapara, V. (2017). Does Trump Have a Grand Strategy? Review of International Affairs, 68 (1168), pp. 62-64.

Treaty between the French Republic and the Federal Republic of Germany on French-German cooperation (1963 January 22), retrieved from https://www.cvce.eu/en/education/unit-content/-/unit/02bb76dfd066-4c08-a58a-d4686a3e68ff/6ead1e5e-71c4-4367-a6d1-15476dfebdc2/ Resources\#68956f73-75cb-4749-a6e2-344c8aad84ba_en\&overlay. Accessed 26 November 2020.

White House. (2020). Remarks by President Trump and President Duda of the Republic of Poland in Joint Press Conference. (2019, June 12), retrieved from https://www.whitehouse.gov/briefings-statements/ remarks-president-trump-president-duda-republic-poland-joint-pressconference-2/. Accessed 2 December 2020.

Wise, N. (2020, October). America's Judiciary Doesn't Look Like America. The Atlantic, retrieved from https://www.theatlantic.com/ideas/ archive/2020/10/americas-judiciary-doesnt-look-like-america / 616692/. Accessed 1 December 2020. 